\title{
Phytoprotection
}

\section{A note on the occurrence of root lesion nematodes under native sand-prairie plant species in the Regional Municipality of Haldimand-Norfolk, Ontario}

\author{
A.W. McKeown, J.W. Potter, M.E. Gartshore et P. Carson
}

Volume 75, numéro 3, 1994

URI : https://id.erudit.org/iderudit/706061ar

DOI : https://doi.org/10.7202/706061ar

Aller au sommaire du numéro

Éditeur(s)

Société de protection des plantes du Québec (SPPQ)l

ISSN

0031-9511 (imprimé)

1710-1603 (numérique)

Découvrir la revue

Citer cet article

McKeown, A., Potter, J., Gartshore, M. \& Carson, P. (1994). A note on the occurrence of root lesion nematodes under native sand-prairie plant species in the Regional Municipality of Haldimand-Norfolk, Ontario. Phytoprotection, 75(3), 139-142. https://doi.org/10.7202/706061ar
Résumé de l'article

Le nématode des lésions des racines (Pratylenchus penetrans), le nématode phytoparasite le plus important du sud de l'Ontario, possède une gamme d'hôtes extrêmement large. À cause de la nécessité de réprimer ces parasites avec des cultures recouvrantes qui sont peu ou pas hôtes, plusieurs espèces indigènes des prairies sablonneuses ont été évaluées pour leur susceptibilité au nématode des lésions. Onze espèces appartenant à quatre familles (Asclepiadaceae, Asteraceae, Poaceae et Fabaceae) ont été identifiées commes des hôtes faibles. Les populations très faibles de $P$. penetrans sur ces espèces indiquent qu'elles pourraient avantageusement servir comme cultures recouvrantes. 


\title{
A note on the occurrence of root lesion nematodes under native sand-prairie plant species in the Regional Municipality of Haldimand-Norfolk, Ontario
}

\author{
Alan W. McKeown', John W. Potter², Mary E. Gartshore ${ }^{3}$, \\ and Peter Carson ${ }^{3}$
}

Received 1994-04-05; accepted 1994-07-27

The root lesion nematode Pratylenchus penetrans, which is the most important plant-parasitic nematode in southern Ontario, has an extremely wide host range. Because of the need to suppress lesion nematodes with cover-crop species which are poor or non-hosts of this parasite, a number of native sand-prairie species were evaluated for susceptibility. Eleven plant species belonging to the families Asclepiadaceae, Asteraceae, Poaceae and Fabaceae were determined to support very low numbers of $P$. penetrans and consequently to have potential as beneficial cover-crops.

McKeown, A.W., J.W. Potter, M.E. Gartshore et P. Carson. 1994. Une note sur l'association entre le nématode des lésions des racines et des espèces végétales indigènes des prairies sablonneuses dans la Municipalité régionale de Haldimand-Norfolk (Ontario). PHYTOPROTECTION 75: 139-142.

Le nématode des lésions des racines (Pratylenchus penetrans), le nématode phytoparasite le plus important du sud de l'Ontario, possède une gamme d'hôtes extrêmement large. À cause de la nécessité de réprimer ces parasites avec des cultures recouvrantes qui sont peu ou pas hôtes, plusieurs espèces indigènes des prairies sablonneuses ont été évaluées pour leur susceptibilité au nématode des lésions. Onze espèces appartenant à quatre familles (Asclepiadaceae, Asteraceae, Poaceae et Fabaceae) ont été identifiées commes des hôtes faibles. Les populations très faibles de $P$. penetrans sur ces espèces indiquent qu'elles pourraient avantageusement servir comme cultures recouvrantes.

Sandy soils in The Regional Municipality of Haldimand-Norfolk, Ontario $\left(42^{\circ} 51^{\prime} \mathrm{N} 80^{\circ} 16^{\prime} \mathrm{W}\right)$ are known to favour root lesion nematodes, Pratylenchus penetrans Cobb, in a wide range of crops (Marks and Townshend 1973; Olthof 1979, 1983; Olthof and Potter 1973, 1977; Potter and Olthof 1974, 1977). Part of the native ecology of these sandy soils is sand prairie (Gartshore et al. 1987), a habitat which supports indigenous plant species uniquely adapted to these soil type and moisture conditions (Brown 1993). Presumably, native sand-prairie plants have coexisted with root lesion nematodes in these soils for millennia and may have developed some tolerance or resistance. Townshend and

1. Horticultural Research Institute of Ontario, Box 587, Simcoe, Ontario, Canada N3Y 4N5

2. Agriculture and Agri-Food Canada Research Station, Vineland Station, Ontario, Canada LOR 2E0

3. R.R. \# 1, Walsingham, Ontario, Canada NOE 1X0 
Davidson (1960, 1962) screened over 100 plant species for susceptibility to the root lesion nematode and to the northern root knot nematode, Meloidogyne hapla Chitwood, but they did not test the species reported below.

We screened a collection of native sand-prairie plants found in the region for plant-parasitic nematodes. Twoyear-old pure stands of each species were planted in $10 \mathrm{~m}$ rows spaced $1.5 \mathrm{~m}$ apart as a private restoration project by Gartshore and Carson (unpublished data), and were sampled on 21 May, 12 August, and 10 November 1993. This block was designed to produce seed of locally collected prairie plants in order to replant 25 ha of former tobacco farmland into native prairie. Isolated clumps of several other species were also sampled at the last date. At each sampling date, each species was sampled by collecting and bulking 10 soil cores $10 \mathrm{~cm} \times 2.5 \mathrm{~cm}$ diam with an Oakfield soil sampler, through the root zone and $5 \mathrm{~cm}$ laterally from the plant crowns. Cores were stored and mixed in plastic bags, and nematodes were assayed from a $50 \mathrm{~g}$ subsample using the Baermann pan technique (Townshend 1963) and counted at 50X with a stereoscopic microscope. In mid-April 1993, samples were collected from three areas of prairie restoration plantings at three elevations on slopes - top, midslope and bottom. The three areas were established under a predominantly volunteer cereal rye (Secale cereale L.)Canada fleabane (Erigeron canadensis L.) cover, a predominantly Canada fleabane cover, and mixed prairie species. Samples were processed as previously described.

A number of species were observed to support very low numbers $1<100$ nematodes $\mathrm{kg}^{-1}$ of soil) of root lesion nematodes, $P$. penetrans, and low counts $\left(<500\right.$ nematodes $\mathrm{kg}^{-1}$ ) of root knot nematodes, Meloidogyne hapla (Table 1). Brown-eyed Susan (Rudbeckia hirta L.) samples showed no root lesion nematodes throughout the season, and butterflyweed (Asclepias tuberosa L.) showed very low counts, while switch grass (Panicum virgatum L.) and Indian grass [Sorghastrum nutans (L.) Nash] samples showed a low root lesion nematode count on only one sampling date. Several species [Liatris cylindracea Michx., Monarda punctata L., Pycnanthemum virginianum L., Echinacea purpurea (L.) Moench] proved to be excellent hosts (> 500 nematodes $\mathrm{kg}^{-1}$ of soil) of the root lesion nematode, which confirmed its presence in the soil; hence the observed low counts were not the result of absence of nematodes. Trace amounts of the ring nematode (Criconemoides sp.) were found in May on Lupinus perennis L. (40 nematodes $\mathrm{kg}^{-1}$ ). Meloidogyne hapla was found on Monarda fistulosa L. and Geum triflorum Pursh (120 and 280 nematodes $\mathrm{kg}^{-1}$, respectively) in August. Stunt nematodes (Tylenchorhynchus spp.) were found on big bluestem (Andropogon gerardi Vitman), L. perennis, F'. virgatum and little bluestem [Schizachyrium scoparium (Michx.) Nash] (400, 40, 20 and 100 nematodes $\mathrm{kg}^{-1}$, respectively), in August. Trichodorid nematodes (20 nematodes $\mathrm{kg}^{-1}$ ) were found on sideoats grama [Bouteloua curtipendula (Michx.) Torr.] on both sampling dates.

Root lesion nematode counts in the three restoration areas were moderate, averaging 380 nematodes $\mathrm{kg}^{-1}$ of dry soil, with no significant differences between areas or elevations (Table 2); these population counts were well below the frequently-used damage threshold of 1000 nematodes $\mathrm{kg}^{-1}$ of soil. Since Townshend and Davidson (1960) determined Canada fleabane as a poor host of root lesion nematode, the presence of Canada fleabane in each area may well explain the low counts.

Sand prairie is an unusual ecological habitat, requiring adaptation to the moisture conditions and soil type. In Ontario, Dore and McNeill (1980) have noted that species of Andropogon, Bouteloua, Sorghastrum, Panicum, and Lespedeza were found co-inhabiting a natural prairie at Spotiswood Lakes $\left(43^{\circ} 30^{\prime} \mathrm{N} 80^{\circ} 20^{\prime} \mathrm{W}\right)$ in Brant County, one of only two areas in the province where Bouteloua was found. Formerly, several of the grass species were grown commercially in the USA in the early part of the century (USDA 1948); 
Table 1. Population densities of Pratylenchus penetrans under selected wild species at three sampling dates in 1993

\begin{tabular}{|c|c|c|c|c|c|}
\hline \multirow[b]{2}{*}{ Plant species } & \multirow[b]{2}{*}{ Common name } & \multicolumn{4}{|c|}{$\begin{array}{l}\text { Population density } \\
\text { (nematodes } \mathrm{kg}^{-1} \text { ) }\end{array}$} \\
\hline & & May & Aug. & Nov. & Average \\
\hline Rudbeckia hirta L. & Brown-eyed Susan & 0 & 0 & 0 & 0 \\
\hline Gaillardia sp. Foug. & Indian-blanket & - & - & 0 & 0 \\
\hline Panicum virgatum $\mathrm{L}$. & Switch grass & 20 & 0 & 0 & 7 \\
\hline Asclepias tuberosa $\mathrm{L}$. & Butterflyweed & 20 & 0 & 8 & 9 \\
\hline Sorghastrum nutans (L.) Nash & Indian grass & 0 & 0 & 40 & 13 \\
\hline Lespedeza capitata (Michx.) & Bush clover & - & - & 40 & 40 \\
\hline Schizachyrium scoparium (Michx.) Nash & Little bluestem & 20 & 0 & 200 & 73 \\
\hline Sporobolus cryptandrus (Torr.) Gray & Sand dropseed & - & - & 120 & 120 \\
\hline Andropogon gerardi Vitman & Big bluestem & 0 & 20 & 340 & 120 \\
\hline Bouteloua curtipendula (Michx.) Torr. & Side-oats grama & 160 & - & 100 & 130 \\
\hline Lupinus perennis $\mathrm{L}$. & Lupin & 80 & 460 & 160 & 233 \\
\hline Andropogon virginicus $\mathrm{L}$. & Broomsedge & - & - & 280 & 280 \\
\hline Monarda fistulosa $\mathrm{L}$. & Wild bergamot & 560 & 280 & - & 420 \\
\hline Liatris cylindracea Michx. & Blazing star & 100 & 120 & 1540 & 587 \\
\hline Geum triflorum Pursh & Three-flowered avens & - & - & 940 & 940 \\
\hline Pycnanthemum virginianum $\mathrm{L}$. & Mountain mint & 20 & - & 5420 & 2720 \\
\hline Monarda punctata L. & Horsemint & 0 & 1040 & 12080 & 4373 \\
\hline Echinacea purpurea (L.) Moench & Purple coneflower & - & - & 11340 & 11340 \\
\hline
\end{tabular}

a Number of root-lesion nematodes per $\mathrm{kg}$ of soil.

Table 2. Population densities of Pratylenchus penetrans at three levels of a prairie restoration planting area in 1993

\begin{tabular}{lccc}
\hline & \multicolumn{3}{c}{$\begin{array}{c}\text { Population density } \\
\text { (nematodes } \mathbf{k g}^{-1} \text { ) }\end{array}$} \\
\cline { 2 - 4 } Restoration area & Top & Mid-slope & Bottom \\
\hline Mixed prairie cover & 360 & 420 & 220 \\
Cereal rye cover & 380 & 320 & 260 \\
Canada fleabane cover & 360 & 340 & 780 \\
\hline
\end{tabular}

a Number of root lesion nematodes per $\mathrm{kg}$ of soil.

therefore, information on production exists for several of these species. Big bluestem and little bluestem, side-oats grama, switch grass, and sand dropseed [Sporobolus cryptandrus (Torr.) Gray] have been recommended for forage, pasture, and conservation uses. Domesticated Rudbeckia sp. has been demonstrated to reduce root lesion nematode populations (J. Brandle, personal com- munication). Domesticated butterfly weed, brown-eyed Susan, and Indianblanket (Gaillardia spp.) are grown already as garden perennials; several of the grasses also show potential for use as ornamental plants. Thus we have identified native species that are well adapted to hot dry sands, have potential for cover, rotation, forage and ornamental use, and that may suppress 
populations of root lesion nematodes. Such plants would be particularly beneficial as cover crops in sandy agricultural areas like the Regional Municipality of Haldimand-Norfolk, where these species are evidently indigenous.

\section{REFERENCES}

Brown, L. 1993. A garden of rarities, Ontario's prairie heritage. Seasons. Federation of Ontario Naturalists. Summer. Pages 20-36.

Dore, W.G., and J. McNeill. 1980. Grasses of Ontario. Monograph 26, Agriculture Canada Research Branch, Ottawa. 566 pp.

Gartshore, M.E., D.A. Sutherland, and J.D. McCracken. 1987. The natural areas inventory of the Regional Municipality of Haldimand-Norfolk. Vol. 1, 112 pp.; Vol. 2, $265 \mathrm{pp}$. The Norfolk Field Naturalists. Simcoe, Ontario.

Marks, C.F., and J.L. Townshend. 1973. Multiplication of the root lesion nematode Pratylenchus penetrans under orchard cover crops. Can. J. Plant Sci. 53: 187-188.

Olthof, Th.A. 1979. Effects of Pratylenchus penetrans and Meloidogyne hapla on potential crops for the tobacco growing areas of southwestern Ontario. Can. J. Plant Sci. 59: 1117-1121.

Olthof, Th.A. 1983. Reaction of six potato cultivars to Pratylenchus penetrans. Can. J. Plant Pathol. 5: 285-288.
Olthof, Th.A., and J.W. Potter. 1973. The relationship between population densities of Pratylenchus penetrans and crop losses in summer maturing vegetables in Ontario. Phytopathology 63: 577-582.

Olthof, Th.A., and J.W. Potter. 1977. Effects of population densities of Meloidogyne hapla on growth and yield of tomato. J. Nematol. 9: 296-300.

Potter, J.W., and Th.A. Olthof. 1974. Yield losses in fall maturing vegetables relative to population densities of Pratylenchus penetrans and Meloidogyne hapla. Phytopathology 64: 1072-1075.

Potter, J.W., and Th.A. Olthof. 1977. Analysis of crop losses in tomato due to Pratylenchus penetrans. J. Nematol. 9: 290295.

Townshend, J.L. 1963. A modification and evaluation of the apparatus for the Oostenbrink direct cottonwool filter extraction method. Nematologica 9: 106-110.

Townshend, J.L., and T.R. Davidson. 1960. Some weed hosts of Pratylenchus penetrans in Premier strawberry plantations. Can. J. Bot. 38: 267-273.

Townshend, J.L., and T.R. Davidson. 1962. Some weed hosts of the northern root knot nematode, Meloidogyne hapla Chitwood, 1949, in Ontario. Can. J. Bot. 40: 543-548.

USDA. 1948. Grass, The Yearbook of Agriculture. United States Dep. Agric. U.S. Government Printing Office, Washington. 892 pp. 